\title{
Teaching Vocabulary to Visually Impaired EFL Learners: A Small Scale Study
}

\author{
Havva ZORLUEL ÖZER ${ }^{\mathrm{a}^{*}}$, Neşe CABAROĞLU $\mathrm{b}^{\mathrm{b}^{* *}}$ \\ aÇukurova Üniversitesi, İngiliz Dili Eğitimi, Adana/Türkiye

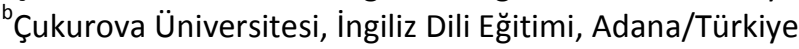

CrossMark

\section{Article Info}

DOI: 10.14812/cufej.379823

Article history:

Received 17.01.2018

Revised 13.03.2018

Accepted 22.03.2018

Keywords:

Teaching English vocabulary

Visually impaired

\begin{abstract}
This qualitative study aims at providing an in-depth account of teaching vocabulary to young English as a foreign language (EFL) learners with visual impairments. The present study investigates how foreign language teachers teach English vocabulary to the visually impaired (VI) young learners, what challenges they face and whether they can cope with these challenges in this particular process. The participants are two EFL teachers working at an elementary and a middle school for blind and visually impaired students in Adana, Turkey. Semi-structured interviews have been utilized to collect data. Content analysis results revealed that both teachers most frequently utilized auditory teaching techniques, used L1 and computer assisted teaching techniques while teaching vocabulary to VI young learners. Semi-structured in-depth interviews also provided insights into the challenges faced while teaching vocabulary to VI young learners. Data showed that the orthography, material shortage, time constraints, and dependency of students on other people to study were the main difficulties experienced by both teachers.
\end{abstract}

\section{Görme Engelli Yabancı Dil Öğrencilerine Kelime Öğretimi: Küçük Ölçekli Bir Çalışma}

\section{Makale Bilgisi}

\section{DOI: 10.14812/cufej.379823}

Makale Geçmişi:

Geliş $\quad 17.01 .2018$

Düzeltme 13.03.2018

Kabul 22.03.2018

Anahtar Kelimeler:

İngilizce kelime öğretimi

Görme engelli

\section{Öz}

Bu nitel çalışmanın amacı görme engelli küçük yaştaki İngilizce öğrencilerine kelime öğretimine dair detaylı bir açıklama getirmektir. Mevcut çalışmada, yabancı dil öğretmenlerinin görme engelli küçük yaştaki öğrencilere İngilizce kelimeleri nasıl öğrettikleri, bu süreçte ne tür zorluklar yaşadıkları ve bu zorluklarla başa çıkıp çıkamadıkları araştırılmıştır. Katılımcılar Türkiye'nin Adana şehrindeki bir görme engelliler ilk ve orta okulunda çalışan iki İngilizce öğretmenidir. Veri toplamak amacıyla yarı-yapılandırılmış görüşmelerden yararlanılmıştır. İçerik analizi sonuçları her iki öğretmenin de görme engelli öğrencilere kelime öğretirken en çok işitsel öğretim tekniklerini, ana dili ve bilgisayar destekli öğretim tekniklerini kullandıklarını ortaya koymuştur. Yarı yapılandırılmış görüşmeler, görme engelli küçük yaştaki öğrencilere kelime öğretirken yaşanan sıkıntılara da ışık tutmuştur. Sonuçlar imla, materyal kısıtlılığı, zaman sıkıntısı ve öğrencilerin ders çalışabilmek için başkalarına olan bağımlılığının öğretmenler tarafından deneyimlenen başlıca zorluklar olduğunu göstermiştir.

*Author:hzorlue@cu.edu.tr 


\section{Introduction}

Education for All Children Act mandates that all children with disabilities have rights to be in an educational setting that is as close to the regular classroom as possible. Special education is increasingly gaining attention from educators and governments throughout the world. To improve the quality of education and service provided, Turkey has also been working on the provision of special education and inclusive education. However, some problems still persist in ensuring the access of students with disabilities or disorders in the curriculum (Sakiz and Woods, 2005). Among many, lack of trained teachers is considered as one of the biggest challenge (ibid.).

It is commonly accepted that visually impaired (VI) learners experience more difficulties in learning a foreign language when compared to sighted learners. This difficulty may arise from the dearth of teaching materials designed specifically for use by VI learners. As in learning other subjects, learning a foreign language requires the use of materials and methods (and techniques) that mostly address the visual channel. For this reason, it is highly important for foreign language teachers to implement methods and materials other than those that require visual clues. This can be quite challenging for teachers, as it requires experience and additional knowledge of special educational needs and methodologies suitable for VI learners (ibid.).

Review of research suggests that visually impaired learners need teachers who have the ability to address their learning styles (e.g. Anthony and Walshaw, 2009;Quek andMcNaill, 2006). It has been reported that teachers do not receive education for teaching disabled students or students with special education needs during their pre-service education in Turkey (Köseler, 2012). This small-scale study delves into a relatively underexplored area of vocabulary teaching to visually impaired learners in a special education school context by two EFL teachers.

\section{Vocabulary Teaching and Visually Impaired/Blind Learners of EFL}

Vocabulary teaching has been one of the most intensively studied areas in foreign language (FL) teaching research (Atay and Kurt, 2006; Bagheri, 2015; Barani et al., 2010; Chou, 2014; Demircioğlu, 2010;Papathanasiou, 2009; Sonbul and Schmitt, 2009; Sun and Dong, 2004). Researchers emphasize the importance of teaching vocabulary in the process of $F L$ teaching to help learners perform successful communication in the target language (Carter and McCarthy, 2013). In the last two decades, it has been acknowledged that "'making students aware of the new words they encounter and motivating students to learn and use the new words" are of considerable value in FL teaching setting (Grabe, 2009, p. 279). This can be accomplished by developing the students' word knowledge which requires mastering a word's orthography, morphology, parts of speech, pronunciation, collocations, meanings and meaning associations, specific uses and register (Grabe, 2009). Since FL learners may have difficulty in mastering some or all of the above aspects while learning second language (L2) vocabulary, it remains a wonder how visually impaired young language students learn the target vocabulary items in FL classrooms.

In recent years, much research has adopted experimental design to investigate the efficacy of various techniques on vocabulary learning of EFL learners. Many of those studies put emphasis on the effect of audio-visual aids on learning L2 vocabulary. It has been found that the audio-visual aids have a positive effect on vocabulary learning of young EFL learners (Sun and Dong, 2004). A study by Atay and Kurt (2006) provided evidence for the benefits of interactive tasks as post-reading activities in enhancing the vocabulary acquisition of Turkish EFL students. Another study with a focus on reading as a way of learning vocabulary was conducted by Sonbul and Schmitt (2009). Similar findings echoed in a study by Sun and Dong (2004), which emphasized the importance of providing additional support for the selected method to work effectively. Besides learning vocabulary from reading, the efficacy of drama activities, games, songs and stories has also been reported in studies by Chou (2014), and Demircioğlu (2010).

As stated earlier, much research has been conducted to investigate teaching vocabulary to English as a Foreign Language (EFL) learners most of whom are sighted students in regular education settings. Nevertheless, with the increasing number of schools for the VI students, it has gained utmost significance for the teachers to develop particular teaching skills to be able to teach these students with 
special needs. Still, studies conducted to understand the phenomenon of teaching English to the VI learners are very limited, and even less with an emphasis on the aspect of vocabulary teaching.

It should be noted that these studies have been conducted with sighted participants in a sighted setting. With the growing emphasis on the equality of opportunity in education in recent years, an increasing number of schools for the VI students have been established and it has gained utmost significance for the teachers to develop particular teaching skills to be able to teach these particular students. There is a relatively small number of research conducted to understand the phenomenon of teaching English to the VI learners(with the exceptions of Başaran, 2012; Koçyiğit and Sabuncu-Artar, 2015; Topor and Rosenblum, 2013). However, when it comes to the aspect of vocabulary teaching in particular, there are even more limited number of studies.

Stein et al. (2011) emphasize the significance of assistive technology for VI students to learn vocabulary in a FL. They propose an orthographic feedback which is designed for a computer-assisted vocabulary learning application developed for blind students or students with visual impairments, as an alternative solution to the overall challenge VI learners face while learning how to spell an L2 vocabulary since "language learners with visual impairments struggle significantly more with acquiring spelling of an L2 vocabulary item than with acquiring its meaning" (Stein et al., 2011). In the study, a questionnaire was administered to $15 \mathrm{VI}$ students and an online survey to $88 \mathrm{VI}$ adults in order to evaluate the efficacy of an "Auditory Vocabulary and Spelling Trainer" program designed. The study provided promising evidence of the benefit of the program in learning vocabulary along with some suggestions for improvement made by the users.

Since there is an obvious gap in both Turkish and international literature in the area of teaching vocabulary to visually impaired EFL learners, the present study aims at filling the gap by providing an insight into the process of teaching vocabulary to the young EFL learners with visual impairments. The term to describe young learners used for this particular research is adopted from Phillips (1993, p.3) who defines young learners as "children from the first year of formal schooling to eleven or twelve years of age". The underlying reason for the focus on young learners in the study is that young learners bring a number of characteristics that makes it more challenging for most of the FL teachers to teach them English. Adding the lack of vision to these characteristics, it becomes crucially important to take these conditions into account while teaching a language. This study examines how language teachers teach English vocabulary to VI young EFL learners, what challenges they faced, and whether they could cope with these challenges in the process. With these in mind, the study aims at answering the following research questions:

1. How do Turkish EFL teachers teach vocabulary to visually impaired young learners?

2. What challenges, if any, do Turkish EFL teachers face while teaching vocabulary to visually impaired young learners?

3. Can Turkish EFL teachers cope with challenges in teaching vocabulary to visually impaired young learners?

3.1. What suggestions do they make to be able to overcome these challenges?

\section{Method}

To understand the particular phenomenon of teaching vocabulary to VI young EFL learners from the viewpoint of Turkish EFL teachers, a descriptive research design based on qualitative data collection and analysis methods was employed in the present study.

\section{Participants}

The research was carried out in a public elementary and middle school for blind and VI students in Adana, Turkey. With an attempt to "select individuals and sites for study because they can purposefully inform an understanding of the research problem and central phenomenon in the study" (Creswell, 2007, p.125), purposive sampling was employed in order to secure information rich cases (Lincoln andGuba, 1985). The participants were two sighted Turkish EFL teachers (T1 and T2) working at an 
elementary and middle school for blind and visually impaired students in Adana. T1 has an experience of 11 years for teaching but she has been teaching visually impaired students for two years in an elementary school for blind and visually impaired students. T2 has been teaching for 15 years, but she has recently been assigned to teach visually impaired students and has been teaching for 2 months in the same school. Both the teachers have approximately 6 to 10 students in their classes. Neither of them has received any formal training for teaching visually impaired students. (However, it should be noted that the participants were invited to an in-service teacher training on Braille one month after the completion of the study.)

\section{Research Context}

This study was conducted at the only school in the city where the researchers lived, particularly founded for the visually impaired and blind students. Since Turkey's education system changed into 4+4+4 education system in 2012-2013 education year, the eight-year primary education has been given in two separate schools. The research site consisted of two schools: elementary and middle. At the time of the study, there were 44 students at elementary, and 51 students at the middle school. At the time this study was carried out, there were only two English teachers: one teaching at the elementary school, and the other at the middle school. Elementary school students (starting from the $2^{\text {nd }}$ grade) took English classes two hours a week. As for the middle school students, students in the $5^{\text {th }}$ and $6^{\text {th }}$ grades took three hours of English lessons weekly while the $7^{\text {th }}$ and $8^{\text {th }}$ grade students took four hours of English lessons in a week.

\section{Data Collection and Analysis}

In order to answer the research questions, semi-structured interviews were conducted with participants. Before the interviews, the participants were given informed consent forms in which the purpose of the interviews to be conducted was described, and by which the participants were informed that they would be assigned labels so that their identities would be kept confidential. This study utilized interviews to collect data because "the expressive power of language provides the most important resource for accounts" (Hammersley and Atkinson, 1995, p.126). Each participant answered demographics related questions and main prompt questions as well as questions that occurred at the course of interview. The main prompt questions included how teachers were teaching vocabulary to their VI students, what type of challenges, if any, they faced while teaching vocabulary to their VI students, whether they could cope with these challenges and whether they had any practical insights about how to cope with these challenges. Interviews were conducted in the school where our participants worked. The language of the interviews was Turkish. Each interview was audio-recorded and lasted 15 to 20 minutes.

The audio-recorded interviews were later transcribed for analysis purposes. To analyze the textual data created from transcription, content analysis was carried out. The interview data were first read for a couple of times in order to become familiar with, and get a general sense of the data. After the transcribed interviews were read over, the segments of information were underlined and labeled with codes. Then, broad themes were formulated from the codes by assigning the related codes into the same themes. Data were read repeatedly in case of the emergence of new themes. As Creswell (2009) states, qualitative data analysis "is an ongoing process involving continual reflection about the data" ( $p$. 184).At the end, three themes emerged in line with the objectives of this study: 1 . techniques used by Turkish EFL teachers to teach vocabulary to VI learners; 2 . challenges in the process of teaching vocabulary to VI learners; and 3. teachers' suggestions to cope with these challenges described earlier.

\section{Results and Discussion}

In line with the research and interview questions, three themes emerged from our data: vocabulary teaching techniques employed by the EFL teachers, challenges they faced in relation to teaching vocabulary to VI learners and suggestions. Table 1 summarizes the techniques teachers used when teaching vocabulary along with its subcategories and relevant examples: 
Table 1.

Techniques Used by Turkish EFL Teachers to Teach Vocabulary to VI Young Learners

\begin{tabular}{|c|c|}
\hline Techniques & Examples \\
\hline Auditory teaching & $\begin{array}{l}\text { T1: "We frequently utilize auditory teaching materials. We help } \\
\text { them learn by hearing." } \\
\text { T2: "We have tape recorders. I record (vocabulary) so that they } \\
\text { could study at home by listening to the tape." }\end{array}$ \\
\hline Using L1 (Turkish) & $\begin{array}{l}\text { T1: "We teach vocabulary with their Turkish counterparts." } \\
\text { T2: "I definitely say the Turkish counterparts of English words." }\end{array}$ \\
\hline Computer assisted teaching & $\begin{array}{l}\text { T1: "Recently, we have smart boards. We can connect to the } \\
\text { internet." } \\
\text { T2: "We are using special computer programs." }\end{array}$ \\
\hline Repetition & $\begin{array}{l}\text { T1: "I ask them to repeat words after me." } \\
\text { T2: "We may be repeating ten times each week." }\end{array}$ \\
\hline Games & $\begin{array}{l}\text { T1: "We often play vocabulary games. They like playing games. For } \\
\text { example, we try to find a new word starting with the last letter of } \\
\text { the previous word." }\end{array}$ \\
\hline
\end{tabular}

Table 1 reveals that both teachers frequently utilized auditory teaching strategies, used L1 and computer assisted teaching strategies while teaching vocabulary to VI young EFL learners. Both teachers emphasized the suitability of auditory teaching strategies to their VI students. They also explained that during the lessons they frequently made use of English songs 'as they learn by hearing'. To aid their learning, $\mathrm{T} 2$ recorded her own or her students' voice when they are repeating the word-both in English and Turkish, and then asked them to listen to it at home to enhance their learning. The teachers agreed on the necessity of L1 usage in the process of teaching vocabulary to their VI students and they both mentioned how they utilized computer assisted teaching strategies, mostly with the help of smart boards in their classes. The importance of the use of assistive technology on teaching VI students has long been acknowledged in educational research as Mulloy et al. (2014, p. 113) states, it "provides students with $\mathrm{VI}$ and blindness access to many school-related activities" which enhances VI students' participation in class activities. Another technique the teachers often employed to teach vocabulary was repetition because of the fact that the learners quickly forget what they learn. It has been acknowledged in the literature that repetition technique is still the most-used strategy (Liao, 2004). Use of vocabulary games that VI students enjoyed playing in the classroom was another alternative technique employed by the participants. The role of language games in teaching/learning vocabulary cannot be denied. It has been reported that, in addition to many other benefits, language games enhance learners' motivation (Chou, 2014; Julkunen, 2001), and creates a flexible and relaxed learning environment that has a positive effect on peer, student and teacher relationships (Ojeda, 2004).

It is seen that the vocabulary teaching techniques the teachers of the VI students use in their language classrooms differ mainly from the techniques used by the teachers of sighted students because of the unavailability of teaching materials appropriate for VI learners. The efficacy of various techniques has been proven on enhancing learners' FL vocabulary, with the audio-visual aids catching the most attention. Therefore, while these most effective techniques, among which are the use of audio-visual aids and multimedia sources, reading and creative drama activities, are being preferred in the majority of sighted classrooms, VI learners can rarely benefit from what their sighted peers do in their learning contexts. The limitation on the use of visual sources such as flashcards, crafts, pictures, educatory videos and all visually related activities deprives the VI learners of effective learning situations. 
Havva ZORLUEL ÖZER, Neşe CABAROĞLU.- Çukurova Üniversitesi Eğitim Fakültesi Dergisi, 47(1), 2018, 151-163

Our second research question aimed at finding out whether Turkish EFL teachers faced challenges while teaching vocabulary to VI young learners. Both teachers explained that they experienced difficulties in this particular process. Table 2 displays those challenges:

Table 2. Challenges Turkish EFL Teachers Face in the Process of Teaching Vocabulary to VI Young Learners

\begin{tabular}{ll}
\hline Challenges & Examples \\
\hline Orthography & T1: “Our biggest problem is reading and writing." \\
T2: "The biggest problem is that they can't learn how to write. \\
They write vocabularies the way they read them." \\
T1: "Vocabulary can be taught easily by using visual aids, but we \\
have this obstacle. We can't use visual teaching materials." \\
T2: “Our coursebook is designed for sighted students! We are \\
having difficulty in following the coursebook."
\end{tabular}

Time constraints

T1: "Course hours are very limited in elementary schools. It is two hours a week." T2:

Dependency

"Four hours per week is not enough (in the middle school)."

T1: "Students do not make revisions because they cannot write. Their parents help them revise."

"They need someone to read them because they cannot study on their own."

Curriculum

T1: "There are too many grammar topics in the $4^{\text {th }}$ grades' coursebooks."

Negative attitudes

T1: "Students are not positive about learning English. They have bias."

Table 2 reveals six different challenges, namely: teaching orthography of English, (lack of or inadequate) teaching materials, time constraints, dependency of students on others, curriculum-related factors, and negative student attitudes towards learning English. Of these challenges, however, orthography seems to be the biggest issue since English is not a phonetic language that is, it is not pronounced as the way it is written and it causes problems for VI students who cannot see the visual representations of words. In the following excerpts, our participants explain this aspect of teaching/learning vocabulary:

T1: 'Since there is quite difference between the pronunciation and written form of the words, we are having much trouble in spelling. Students can easily learn how to say the words since they learn by hearing. It is much for difficult for them to write.

T2: 'I can't decide whether I should teach them how to write or not, or whether it is enough for them just to learn how to say the words correctly.'

In the literature, the challenge VI students face with while acquiring the orthography of a FL has also been clearly pointed out by Stein et al. (2011) who stressed the difficulty VI learners experience when learning how to spell in a FL. The authors suggested that the need for a computer program designed specifically to help people with visual impairments learn the orthography of a FL.Another challenge Turkish EFL teachers faced while teaching VI students was the lack of teaching materials that are useful and accessible for these learners with specific needs. The difficulty experienced by the teachers results from the fact that most teaching materials are primarily based on visualization, which is also stressed by Boguslaw (2000, p.1) who points to the scarcity of teaching "materials suitable for learners requiring 
non-visual methods". The dependency of the educational process on visualization was also described as an obstacle while teaching VI students in Koçyiğit and Sabuncu-Artar's (2015) study.Other challenges common to both teachers involved time-constraints and the reliance of VI students on other people in order to study. Teachers explained that classroom hours, two hours a week for elementary school students and four hours a week for middle school students, were not enough for EFL students, especially for VI- EFL students who could not study on their own and needed someone to help them study at home as they could not read and write effectively. Therefore, classroom is the only place where VI students are exposed to language and where they can study English.

Apart from all these challenges faced by both teachers more or less, T1 complained about the curriculum designed for $4^{\text {th }}$ grades and negative attitudes of students towards English. She stated that the curriculum in $4^{\text {th }}$ grade was loaded with too many grammar topics while it was more tolerable in $2^{\text {nd }}$ and $3^{\text {rd }}$ grades in which the focus was on vocabulary teaching. As for the negative attitudes of students towards English language, T1 stressed that students with former experience in learning English had bias towards FL learning and she attributed the reason to students' negative learning experiences in language learning.

When teachers were asked if they could manage to overcome these challenges mentioned above, they clearly stated that they could not. Consequently, teachers were asked if they could make any suggestions in order to be able to overcome these difficulties. Table 3 shows the suggestions made by the teachers:

Table 3.

Suggestions Made by Turkish EFL Teachers to Overcome Challenges Faced in the Process of Teaching Vocabulary to VI Young Learners

\begin{tabular}{ll}
\hline Suggestions & Examples \\
\hline Pedagogical training & $\begin{array}{l}\text { T1: "It may be beneficial if pre-service teacher trainees would } \\
\text { train here (school for the visually impaired)." } \\
\text { T2: "I think we should be trained for one or two months before } \\
\text { we start teaching here. We need to learn how to write in Braille. } \\
\text { That way we will be able read what the students write." } \\
\text { T1: "Having simple audio story books would be beneficial. } \\
\text { We could be provided with Braille books." } \\
\text { T2: "There should be books specifically designed for visually } \\
\text { impaired students. I wish we had coursebooks as audio files." } \\
\text { T1: "I would love the course hours to be increased very much." } \\
\text { T2: "Course hours should be increased for students with visually } \\
\text { impaired students." } \\
\text { T1: "There are computer program for VI students. I have not yet } \\
\text { discovered such kind of a program for English language learning } \\
\text { but it would be very beneficial." }\end{array}$ \\
\hline
\end{tabular}

As can be seen in Table 3, both participants put emphasis on the necessity of formal training for preservice and in-service EFL teachers for teaching learners with special needs, in particular for VI learners. As neither of them had received such kind of training in university, they found it challenging to teach their VI students. A focus on formal training was also strongly stressed by in the relevant literature (Başaran, 2012; Koçyiğit and Sabuncu-Artar, 2015; Maguvhe, 2015). Other suggestions made by the participants included: increasing course hours, provision of such supplementary materials as audio books, and assistive technology. In relation to the course materials, teachers expressed that they were 
required to use the same course book with that of sighted students when teaching to VI students. They stated that they could not efficiently use the course book as it included many visual aspects. Additionally, both teachers emphasized the necessity of course books designed specifically for VI students including audio aspect to ease language teaching.With regards to this point, the focus on auditory materials while teaching VI learners has also been emphasized strongly in literature (Mulloy, 2014). As Siligo $(2005$, p. 33 ) states "students who are visually impaired are much more comfortable with aural input." Therefore, teachers should utilize auditory materials in order for VI learners to access information (Tuncer and Altunay, 2006). Other than course books, both teachers stressed out the need for additional audio teaching materials, such as audio story books, as well as teaching resources in Braille. As to the suggestion related to the introduction/ provision of assistive technology, Siligo (2005, p. 32) states, "with the use of assistive technologies...teaching students with severe visual impairments need not be an insurmountable challenge". Since utilizing assistive technology is considered as of utmost importance while teaching VI students, national and local education administrators need to provide teachers with the access to assistive technology in classrooms. Still, since it is highly likely that teachers may not be competent enough to be able to use assistive technology in classroom, they may need to be informed about the available programs designed specifically for VI learners and trained about how to use it effectively in their classrooms.

As stated previously, classroom is the only place for VI learners to study and learn English. The participants of the present study reported that outside the classroom their students were dependent on others, which made it impossible to study at home, as their parents/siblings were not good at languages. Therefore, both teachers in this research demanded for an increase in the course hours for classes with VI students. That way, their students would to be exposed to the TL more often and could be given an opportunity to compensate for the times they could not study at home.

\section{Conclusion}

This small-scale qualitative research examined vocabulary teaching techniques used by two Turkish EFL teachers working at an elementary and a middle school for visually impaired students. The challenges faced by these two EFL teachers and suggestions made to be able to overcome these challenges were also examined in semi-structured interviews. Content analysis of interview data revealed three themes, namely techniques, challenges and suggestions. Main implications emerged from the suggestions teachers made in order to be able to cope with the challenges experienced in vocabulary teaching process. Of these, providing pre-service and in-service training programs for teachers seem to be the most apparent. Pre-service teachers can be offered specific courses on teaching students with special needs. In addition, the Ministry of National Education should hold in-service training programs for teachers working with VI learners more often and regularly.

Further research involving classroom observations would be conducted to shed more light on the issue of teaching English to $\mathrm{VI}$ young learners, with the emphasis on vocabulary teaching. Additional research could also be carried out in order to see whether teaching techniques or difficulties experienced by EFL teachers differ while teaching vocabulary to adult VI learners. 


\section{Türkçe Sürümü}

\section{Giriş}

Çocuk Haklarına Dair Sözleşme'de yer alan "Eğitim her çocuğun hakkıdır." maddesi engelli çocukların mümkün olduğunca normal eğitim ortamlarında eğitim alabilmelerini gerektirmektedir. Diğer ülkeler gibi Türkiye de eğitim kalitesini yükseltmek amacıyla özel eğitim ve kaynaştırma eğitimi üzerine iyileştirme çalışmalarına devam etmektedir. Ancak yine de engelli veya rahatsızlığı olan öğrencilere erişime ilişkin problemler müfredat kapsamında varlığını sürdürmektedir (Sakiz ve Woods, 2005).

Görme engelli öğrencilerin yabancı dil öğrenirken görme yetisine sahip öğrencilere kıyasla daha çok zorlandıkları kabul edilmektedir. Bu zorlukların bir kısmı özellikle görme engelli öğrenciler için tasarlanan öğretim materyallerinin eksikliğinden kaynaklanmaktadır. Diğer derslerde olduğu gibi, yabancı dil derslerinde de öğretim yöntem ve teknikleri çoğunlukla görsel materyallere dayalıdır. Bu sebeple, yabancı dil öğretmenlerinin görsel ögeler kullanmayı gerektirmeyen öğretim yöntem ve tekniklerine yer vermeleri oldukça önemlidir. Ancak böyle bir uygulama deneyim, özel eğitime dair donanım, ve görme engelli öğrenciler için uygun yöntem bilgisi gerektirdiği için öğretmenler için zorlayıcı olmaktadır.

Alan taraması görme engelli öğrencilerin kendi öğrenme stillerine uygun eğitim verebilecek öğretmenlere ihtiyacı olduğunu ortaya koymaktadır (Anthony ve Walshaw, 2009; Quek ve McNaill, 2006). Ancak Türkiye'de öğretmen adaylarının öğretmen yetiştirme eğitimi süresince engelli veya özel eğitime ihtiyacı olan öğrencilere nasıl öğretim yapacaklarına dair eğitim almadıkları ortaya konmuştur (Köseler, 2012). Söz konusu küçük ölçekli çalışma iki İngilizce öğretmeninin bir özel eğitim okulundaki görme engelli öğrencilere nasıl kelime öğrettiklerini araştırmaktadır.

\section{Yöntem}

\section{Katılımcılar}

Bu çalışma Türkiye'nin Adana ilinde yer alan kör ve görme engelliler ilk ve ortaokulunda gerçekleştirilmiştir. Katılımcılar görme yetisine sahip iki İngilizce öğretmenidir (Ö1, Ö2). Ö1'in 11 yıllık öğretmenlik deneyimi vardır; ancak görme engelli ilkokul öğrencilerine iki yıldır İngilizce öğretmektedir. Ö2 ise 15 yıllık öğretmenlik deneyimine sahiptir; fakat kör ve görme engelliler ortaokulunda iki aydır görev yapmaktadır. Her iki öğretmenin de sınıflarında yaklaşık olarak altı ile 10 arası öğrenci bulunmaktadır. Öğretmenlerden ikisi de görme engelli öğrencilere İngilizce öğretmek için herhangi bir eğitim almamıştır. (Ancak katılımcıların bu çalışmanın tamamlanmasından bir ay sonra Braille alfabesi üzerine bir hizmet-içi eğitime davet edildikleri not düşülmelidir.)

\section{Veri Toplama ve Analizi}

Araştırma sorularını cevaplandırabilmek amacıyla katılımcılarla yarı-yapılandırılmış görüşmeler yapılmıştır. Görüşmelerden önce katılımcılara yapılacak olan görüşmelerin amaçlarının anlatıldığı, ve çalışma raporlarında kimliklerinin saklı tutulacağının temin edildiği bir rıza formu verilmiştir. Bu çalışmada veri toplamak için görüşmelerden faydalanılmasının sebebi dilin ifade gücünün en verimli kaynak olduğunun düşünülmesidir (Hammersley ve Atkinson, 1995). Her bir katılımcı bir takım demografik soruları ve esas görüşme sorularını cevaplandırmıştır. Esas görüşme sorularından bazıları öğretmenlerin görme engelli öğrencilere nasıl kelime öğrettikleri, kelime öğretiminde ne tür zorluklarla karşılaştıkları, bu zorlukların üstesinden gelip gelemedikleri, ve bu zorlukları yenebilmek için ne tür önerilerde bulunabilecekleri olmuştur. Görüşmeler Türkçe gerçekleşmiş, her bir görüşme yaklaşık olarak 15-20 dakika sürmüş, ve kayıt altına alınmıştır.

Kayıt altına alınan görüşmeler analiz amacıyla çevri yazılmıştır. Çevriyazıdan elde edilen metinsel verinin analizi için içerik analizi uygulanmıştır. Veriye aşinalık açısından her bir görüşme verisi bir kaç kere okunmuştur. Daha sonra veri bölümleri altı çizilerek ve notlar alınarak kodlanmıştır.ilişkili kodlar 
birleştirilerek temalar oluşturulmuştur. Yeni temaların ortaya çıkması intimaline karşı veri kodlama işlemi tekrarlanmıştır. Creswell'in (2009) de belirttiği üzere nitel veri analizi veri hakkında sürekli yansıııcı düşünmede bulunmayı gerektiren ve yinelenen bir süreçtir. Analiz sonunda çalışmanın amaçlarıyla uyumlu olarak üç tema ortaya çıkmıştır: 1 . görme engelli öğrencilere kelime öğretiminde kullanılan teknikler, 2. bu süreçte yaşanan zorluklar, 3. öneriler.

\section{Bulgular ve Tartışma}

Ingilizce öğretmenlerinin görme engelli öğrencilere nasıl kelime öğrettiklerini araştırmayı amaçlayan birinci araştırma sorumuza istinaden, yapılan görüşmelere uygulanan içerik analizi sonuçları her iki öğretmenin de görme engelli öğrencilere İngilizce kelime öğretiminde işitsel öğretim tekniklerinden faydalandıklarını, ve bilgisayar destekli öğretim stratejileri kullandıklarını göstermiştir. Mulloy ve diğerleri'nin (2014) de belirttiği üzere görme engelli öğrencilerin eğitiminde, çeşitli okul aktivitelerine erişimi sağlayarak görme engelli öğrencilerin derse katılımını artıran bilgisayar destekli eğitimden faydalanılması oldukça önemlidir. Ek olarak, sonuçlar her iki öğretmenin de İngilizce kelimeleri Türkçe karşılıklarıyla öğrettiklerini, ve sık sık tekrara başvurduklarını göstermiştir. Bunların yanı sıra, öğretmenlerden Ö1 kelime öğretimini kelime oyunlarıyla pekiştirdiğini vurgulamıştır.

İkinci araştırma sorumuz olan öğretmenlerin görme engelli öğrencilere İngilizce kelime öğretirken ne tür zorluklarla karşılaştıklarına dair altı farklı zorluk ortaya çıkmışır. Bunlardan ilkinin Ingilizcenin okunuşu ve yazılışındaki farklııktan kaynaklandığı gözlenmiştir. Her iki öğretmen de görme engelli öğrencilerin özellikle İngilizce kelimelerin yazıışında zorlandıklarını belirtmişlerdir. Görme engelli öğrencilerin İngilizce öğrenirken yazım ve imlada zorlandıkları Stein ve diğerleri (2011) tarafından da vurgulanmıştır. Bir diğer zorluk öğretim materyalleri eksikliğinden kaynaklanmaktadır. Her iki öğretmen de görme engelli öğrencilerin görme yetisine sahip öğrenciler ile aynı ders kitaplarını kullanıyor olmalarından yakınmışlardır. Öğretim materyallerinin ve eğitim sürecinin büyük ölçüde görselliğe dayalı olmasının yarattığı sıkıntılar diğer araştırmacıların da dikkatini çekmiştir (Boguslaw, 2000; Koçyiğit ve Sabuncu-Artar, 2015). Ingilizce öğretiminde yaşanan zaman kısıtılığı ise bir başka zorluk olarak ortaya çıkmıştır. Öğretmenler ilkokul ve ortaokuldaki İngilizce ders saatlerinin görme engelli öğrenciler için yetersiz olduğunu ifade etmişlerdir. Ayrıca görme engelli öğrencilerin ders çalışmak için başkalarına ihtiyaç duyması da ayrı bir zorluktur. Tüm bunlara ek olarak, Ö1 dördüncü sınıfların ders kitaplarında çok fazla dilbilgisi konusu yer aldığını, ve öğrencilerin dil öğrenmeye karşı olumsuz tutumlar beslediklerini deneyimlenen zorluklar olarak bildirmiştir.

Üçüncü araştırma sorumuz öğretmenlerin yukarda yer alan zorlukların üstesinden gelip gelemediğini incelemiş, ve her iki öğretmenden de gelen hayır yanıtı üzerine alt araştırma sorusu bu zorlukları yenmek için öğretmenlerin önerilerini araştırmıştır. Her iki öğretmenin de öğretmen yetiştirme programlarııı İngilizce öğretmen adaylarını görme engelli veya özel eğitime ihtiyaç duyan öğrencilere eğitim vermek için hazırlamaları gerektiği görüşünde oldukları ortaya konmuştur. Bu öneri alan taramalarında da karşımıza çıkan olgulardan biridir (Başaran, 2012; KoçyiğitveSabuncu-Artar, 2015; Maguvhe, 2015). Ek olarak, öğretmenler görme engelli öğrenciler için öğretim materyalleri geliştirilmesi, ve ders saatlerinin yükseltilmesi önerilerinde bulunmuşlardır. Ö1 görme engelli öğrenciler için tasarlanan bilgisayar programlarının varlığından bahsetmiş, ve bu tür programların İngilizce eğitimi için de olması gerektiğini belirtmiştir.Siligo (2005) da görme engelli öğrencilerin eğitiminde yaşanan bir takım sıkıntıların bilgisayar destekli eğitim ile aşılabileceği görüşündedir. Bu sebeple, milli eğitim müdürlükleri görme engelli öğrencilerin sınıflarında teknolojiye erişim desteği sağlamalıdır. Öğretmenlerin bilgisayar destekli eğitime aşina olmamaları mümkün bir durum olabileceğinden, milli eğitim müdürlükleri teknolojinin eğitim ve öğretimde nasıl etkin bir şekilde kullanılabileceğine dair hizmet-içi eğitimler düzenlemelidir.

\section{Sonuç}

Bu küçük ölçekli çalışma Türk öğretmenler tarafından görme engelli öğrencilere kelime öğretiminde kullanılan öğretim yöntem ve tekniklerini araştırmıştır. Ayrıca, görme engelli öğrencilere İngilizce kelime öğretimi sırasında karşıaşılan zorluklar, ve bu zorlukların üstesinden gelebilmek için yapılan öneriler de yarı-yapılandırılmıs görüşmeler aracılığıyla incelenmiştir. İçerik analizi sonuçları kullanılan teknik, 
Havva ZORLUEL ÖZER, Neşe CABAROĞLU.- Çukurova Üniversitesi Eğitim Fakültesi Dergisi, 47(1), 2018, 151-163

karşılaşılan zorluk, ve yapılan önerileri üç tema altında ortaya koymuştur.Öğretmenler tarafından yapılan önerilere dayanılarak bir takım çıkarımlarda bulunulmuştur. Bunlardan en göze çarpanı öğretmen yetiştirme programları ve hizmet-içi eğitim uygulamalarına yöneliktir. Üniversiteler öğretmen adaylarına özel eğitime ihtiyaç duyan öğrencilere İngilizce öğretimi dersi sunmalıdır. Ayrıca, Milli Eğitim Bakanlı̆̆ı özel eğitim okullarında çalışan öğretmenler için daha sık hizmet-içi eğitim programları düzenlemelidir.

Görme engelli öğrencilere İngilizce öğretiminin daha detaylı incelenmesi için sınıflarda gözlem yapmayı da içeren daha fazla çalışma yapılmalıdır. Diğer bir çalışma alanı ise görme engelli öğrencilere Ingilizce öğretirken kullanılan öğretim yöntem ve tekniklerin, ya da karşılaşılan zorlukların, farklı yaş grupları arasında değişiklik gösterip göstermediğine bakmak olabilir. Zira söz konusu çalışma yalnızca ilkokul ve ortaokul öğrencilerine İngilizce kelime öğretimini araştırmıştır. İlerideki çalışmalar lise ve yüksek öğretim düzeyinde yürütülebilir. 


\section{References}

Anthony, G., \&Walshaw, M. (2009). Effective pedagogy in mathematics. $1^{\text {st }}$ ed. [ebook], Geneva, Switzerland: International Academy of Education.

Atay, D., \& Kurt, G. (2006). Elementary school EFL learners' vocabulary learning: The effects of post reading activities. The Canadian Modern Language Review, 63(2), 255-273.

Bagheri, V. (2015). The impact of verbal and visual techniques on vocabulary achievement of Iranian high school students.Advances in Asian Social Science, 6(4), 1071-1084.

Barani, G., Mazandarani, O., \& Seyyad-Rezaie, S. H. (2010).The effect of application of picture into picture audio-visual aids on vocabulary learning of Iranian EFL learners.Procedia, 2, 5362-5369.

Başaran, S. (2012). Teaching English to visually impaired students in Turkey: A case study. Energy, Education, Science and Technology Part B: Social and Educational Studies, 2, 217-226.

Boguslaw, M. (2000). Learning from experience: Mobility and daily living skills in an English language classroom. Retrieved from:http://www.icevieurope.org/cracow2000/proceedings/chapter05/05$\underline{08 . d o c}$

Carter, R., \& McCarthy, M. (2013). Vocabulary and language teaching. London: Routledge.

Chou, M. (2014). Assessing English vocabulary and enhancing young English as a foreign language (EFL) learners' motivation through games, songs and stories.Education, 3-13(42/3), 284-297.

Creswell, J. W. (2009). Research design: Qualitative, quantitative, and mixed-methods approaches. Los Angeles, CA: Sage.

Creswell, J. W. (2007). Qualitative inquiry and research design. Thousand Oaks: Sage.

Demircioğlu, S. (2010). Teaching English vocabulary to young learners via drama. Procedia, 2, 439-443.

Grabe, W. (2009). Reading in a second language: Moving from theory to practice. NY: Cambridge.

Hammersley, M., \& Atkinson, P. (1995).Etnography: Principles in practice. London: Routledge.

Julkunen, K. (2001). Situation-and-task-specific motivation in foreign language learning. In Z. Dörnyei,\& R. Schmidt (Eds.). Motivation and second language acquisition (pp.29-41). Honolulu: University of Hawai'I Press.

Koçyigit, N., \& Sabuncu-Artar, P. (2015). A challenge: Teaching English to visually impaired learners. Procedia, 199, 689-694.

Köseler, H. (2012). Görme engelliler için fen bilgisi ve matematik eğitimi, [Science and mathematics for visually impaired]. Retrieved from: http://www.halilkoseler.com

Lincoln, Y. S., \&Guba, E. G. (1985). Naturalistic inquiry. Newbury Park, CA: Sage.

Maguvhe, M. (2015). Teaching science and mathematics to students with visual impairments: Reflections of a visually impaired technician. African Journal of Disability, 4(1), Art.\#194, 6 pages.

Mulloy, A. M., Gevarter, C., Hopkins, M., Sutherland, K. S., \&Ramdoss, S. T. (2014).Assistive technology for students with visual impairments and blindness. In G. E. Lancioni, \& N. N. Singh (Eds.). Assistive technology for people with diverse abilities (pp.113-156).

Ojeda, F. A. (2004).The role of word games in second-language acquisition: Second language pedagogy, motivation and lucid tasks (Master's thesis, University of Florida, USA). Retrieved from: http://etd.fcla.edu/UF/UFE0003980/ojeda f.pdf

Papathasiou, E. (2009).An investigation of two ways of presenting vocabulary.ELT Journal, 63(4), 313322.

Phillips, S. (1993). Young learners. Oxford: Oxford.

Quek, F., \& McNeill, D. (2006).Embodiment awareness, mathematics discourse, and the blind.Annals of the New York Academy of Sciences, 1093, 266-279. 
Havva ZORLUEL ÖZER, Neşe CABAROĞLU.- Çukurova Üniversitesi Eğitim Fakültesi Dergisi, 47(1), 2018, 151-163

Sakiz, H., \& Woods, C. (2005). Achieving inclusion of students with disabilities in Turkey: Current challenges and future prospects. International Journal of Inclusive Education, 19(1), 21-35.

Siligo, W. R. (2005).Enriching the ensemble experience for students with visual impairments. Music Educators Journal, 91(5), 31-36.

Sonbul, S., \& Schmitt, N. (2009). Direct teaching of vocabulary after reading: Is it worth the effort?.ELT Journal, 64(3), 253-260.

Stein, V., Nesselrath, R., Alexandersson, J., \& Tröger, J. (2011).Designing with and for the visually impaired: Vocabulary, spelling and the screen reader. CSEDU, 2. Retrieved from: http://avos.sb.dfki.de/sites/default/files/results_paper.pdf

Sun, Y., Dong, Q. (2014).An experiement on supporting children's English vocabulary learning in multimedia context.Computer Assisted Language Learning, 17(2), 131-147.

Topor, I., \&Rosenblum, L. P. (2013).English language learners: Experiences of teachers of students with visual impairments who work with this population. Journal of Visual Impairment \& Blindness, 107(2), 79-91.

Tuncer, A. T., Altunay, B. (2006). The effect of summarization-based cumulative retelling strategy on listening comprehension of college students with visual impairments.Journal of Visual Impairment \& Blindness, 100(6), 353-365. 